\title{
Languages in Contact: An Exploration of Stability and Change in the Solomon Islands
}

\author{
Angela Terrill \\ RADBOUD UNIVERSITY, NIJMEGEN, AND \\ MAX PLANCK INSTITUTE FOR PSYCHOLINGUISTICS, NIJMEGEN
}

\begin{abstract}
The Papuan-Oceanic world has long been considered a hotbed of contactinduced linguistic change, and there have been a number of studies of deep linguistic influence between Papuan and Oceanic languages (like those by Thurston and Ross). This paper assesses the degree and type of contactinduced language change in the Solomon Islands, between the four Papuan languages - Bilua (spoken on Vella Lavella, Western Province), Touo (spoken on southern Rendova, Western Province), Savosavo (spoken on Savo Island, Central Province), and Lavukaleve (spoken in the Russell Islands, Central Province) - and their Oceanic neighbors. First, a claim is made for a degree of cultural homogeneity for Papuan and Oceanic-speaking populations within the Solomons. Second, lexical and grammatical borrowing are considered in turn, in an attempt to identify which elements in each of the four Papuan languages may have an origin in Oceanic languages - and indeed which elements in Oceanic languages may have their origin in $\mathrm{Pa}$ puan languages. Finally, an assessment is made of the degrees of stability versus change in the Papuan and Oceanic languages of the Solomon Islands.
\end{abstract}

1. INTRODUCTION. ${ }^{1}$ This paper explores patterns of linguistic borrowing between the Oceanic languages of the Solomon Islands and their four Papuan neighbors: Bilua (spoken on Vella Lavella, Western Province), Touo (known in the literature as Baniata, spoken on southern Rendova, Western Province), Savosavo (spoken on Savo Island, Central Province), and Lavukaleve (spoken in the Russell Islands, Central Province).

The Papuan and Oceanic languages of Oceania have become rather famous for the extremely high degree of borrowing between certain Oceanic and Papuan languages. Malcolm Ross's work has been important in this field: he has described cases of massive structural borrowing, for instance, by the Oceanic language Takia from the Papuan lan-

1. This work was supported by a grant from the Nederlandse Organisatie voor Wetenschappelijk Onderzoek. I would also like to thank the Max Planck Institute for Psycholinguistics, Nijmegen, for their hospitality during the latter stages of this work. I am grateful to Brenda Higgie Boerger, Michael Dunn, Bethwyn Evans, Eva Lindström, Pieter Muysken, Ger Reesink, Edgar Suter, Claudia Wegener, and two anonymous reviewers for comments on earlier drafts of this paper. 
guage Waskia on the island of Karkar, which has led to the development of his concept of metatypy - structural borrowing by one language on the pattern of another, which has led to structural identity in various grammatical subsystems (Ross 2001a).

This paper presents data from the other end of the scale. In the Solomon Islands the situation is very different: here is an example of languages whose speakers are in constant contact, yet which have borrowed relatively little linguistic material over the last 3,500 years. This is an important point to note, as social conditions do not appear to differ markedly from a place like Karkar, and a full account of patterns of borrowing in the Solomon Islands must account for this very different picture.

This paper describes in turn linguistic candidates for borrowing from Oceanic languages into Papuan languages. It examines for each linguistic category the extent to which the four Papuan languages may have borrowed this material from their Oceanic neighbors. The results should provide insight into exactly what linguistic material has passed from Oceanic into Papuan languages during the past few thousand years that they have presumably been in contact. In fact, of the four Papuan languages of the Solomon Islands discussed here, Bilua seems to show considerably more traces of Oceanic features than the other three. This is particularly interesting given that the Oceanic and Papuan populations do not differ markedly in terms of material culture or social organization. This paper presents evidence that long-term social contact can coexist with minor linguistic influence, and that long-term contact does not necessarily entail major structural borrowing, even over a time frame of thousands of years. This study is thus intended to add something to our understanding of the possible forms that long-term language contact can take.

Two theoretical issues are worth mentioning here. First, a major limiting point of this study is that, while there is good information on past stages of the Oceanic languages, there is only synchronic information on the Papuan languages. All that can be done is to compare the current states of the Papuan languages. Second, there is a major distinction in language contact between situations of change due to language shift, and change due to restructuring of a speaker's own language on the model of another language in which they are bilingual. The latter type of change concerns us here.

1.1 THE LANGUAGES OF THE SOLOMON ISLANDS. The Oceanic languages of the Solomon Islands belong to two subgroups of the Oceanic family of the vast Austronesian family: the Northwest Solomonic linkage, a branch of the Meso-Melanesian cluster, and the Southeast Solomonic family, a branch of Central-Eastern Oceanic (Lynch, Ross, and Crowley 2002). The division cuts the Solomon Islands in two at the southern end of Santa Isabel. Thus, the Papuan language Lavukaleve, spoken in the Russell Islands, straddles the divide between the two Oceanic groupings. The four Papuan languages are scattered at the periphery of the larger islands (see map 1 for the locations of all languages and places mentioned).

Despite efforts to find a genealogical relationship between the four Papuan languages of the Solomon Islands, so far any demonstration of such a relationship has been elusive. Work by Ross (2001b) on the pronouns is suggestive, but by his own account not conclusive, and has not been supported lexically; see Dunn and Terrill (forthcoming) for a recent assessment. This is an important point, as it diminishes the possibility that any structures shared by 
any of the Papuan languages can be attributed to shared genealogical relationship; rather, they must be attributed to contact—or, of course, chance or parallel development.

For the first time, enough data are available on all four Papuan languages to make an attempt of this kind possible, in the form of grammatical descriptions for Bilua (Obata 2003), Savosavo (Wegener 2008), and Lavukaleve (Terrill 2003a), and unpublished field notes for Touo (Terrill and Dunn n.d.).

The geographical situations of these languages are interestingly different. Bilua is spoken on an island that forms the edge of a hub of interaction in the Western Province; that is, there is frequent daily contact between people living in the islands in this area. Touo is spoken on the remote southern half of the large island of Rendova - the northern half is inhabited by Ughele speakers. Savosavo is spoken on a small island off the coast of Guadalcanal. Lavukaleve is spoken on a rather isolated group of islands far away from daily interaction with other languages. Today, Bilua speakers speak Solomon Islands Pijin as well as other Solomon Island languages, and there is a high degree of intermarriage between Bilua people and people of other islands (Obata 2003:1-2). There is a high degree of multilingualism among Touo speakers as well, mainly with Ughele and Roviana (Dunn 2007, Terrill and Dunn 2003). Wegener speaks of multilingualism of Savo people both with Pijin and with the Oceanic languages of Gela (central Solomons)

\section{MAP 1. SOLOMON ISLANDS LANGUAGES MENTIONED IN THE TEXT (after Tryon and Hackman 1983)*}

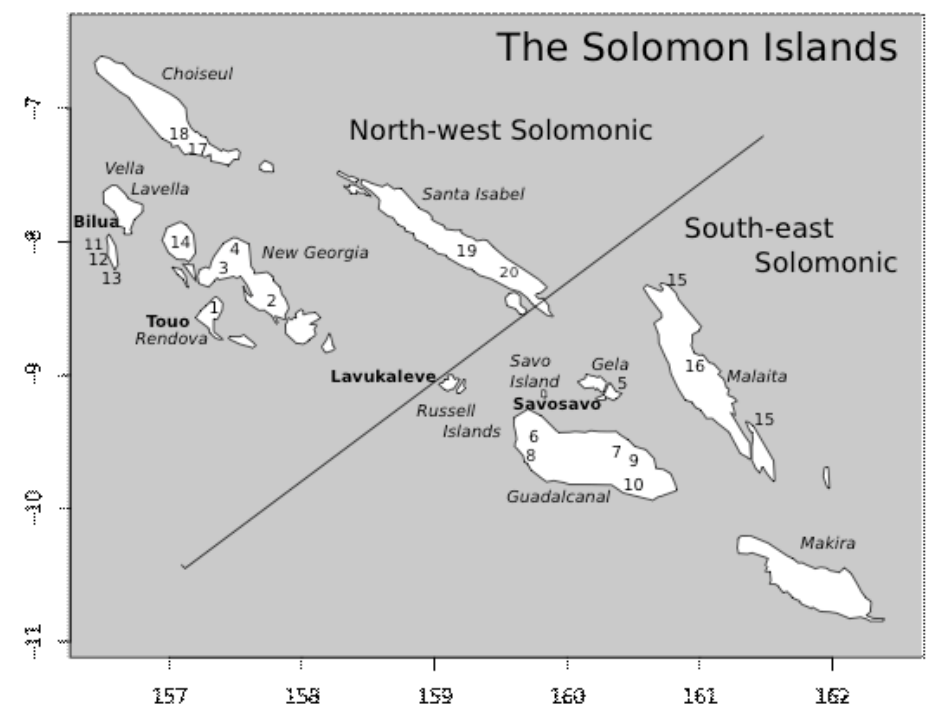

* Key: Papuan languages in bold, Oceanic languages represented by numbers as below:

$\begin{array}{llll}\text { 1 Ughele } & 6 \text { Nginia } & 11 \text { Ghanongga } & 16 \text { Kwaio } \\ 2 \text { Marovo } & 7 \text { Paripao } & 12 \text { Lungga } & 17 \text { Avasö } \\ 3 \text { Roviana } & 8 \text { Ghari } & 13 \text { Simbo } & 18 \text { Lömbaumbi } \\ 4 \text { Kusage } & 9 \text { Longgu } & 14 \text { Kolombangara } & 19 \text { Kokota } \\ 5 \text { Gela } & 10 \text { Tolo } & 15 \text { Lau } & 20 \text { Cheke Holo }\end{array}$


and Ghari (north coast of Guadalcanal) (Wegener 2008). By contrast, intermarriage between Lavukaleve speakers and speakers of other languages is not common, and knowledge of Pijin is confined to those who have left the islands and returned. Particularly in the west of the Russells, other languages apart from Lavukaleve are not heard on a daily basis. There is no reason to think that this situation has changed substantially from precontact times (Terrill 2002).

1.2 APPROACH. In order to determine that language contact has occurred, first a case must be made for social contact having occurred between the speakers of the languages in question. This paper first discusses evidence for cultural homogeneity in the Solomons as a whole; this is not to say that the entire Solomons is culturally uniform, but rather that there is a certain degree of cultural homogeneity, pointing to cultural interaction between different groups within the Solomons. Even after establishing that particular cultures have been in contact, it still cannot be assumed that homogenous linguistic structures point to language contact having occurred. A particular limitation is that, while there is detailed evidence on the histories of the Oceanic languages of the Solomon Islands, there is no similar evidence on the histories of the Papuan languages. There is absolutely no information on their prior states, apart from what can be gleaned from internal reconstruction in each language.

This is a major limitation to any study of the histories of these languages. Also it is not known for certain whether the Papuan languages of the Solomon Islands form a genetic group; recent appraisals have been negative on this point. The approach taken here is that if it can be shown that there is evidence of social contact in a given population, and if it can be shown that there is a certain degree of shared linguistic structures in a given language and one or more neighbors, and if those linguistic structures are most likely not shared simply because of chance or the limited design space of certain linguistic elements, then it can be inferred that the given linguistic structure most likely appears in the given language through borrowing.

The structure of this paper is as follows. First the paper presents certain aspects of cultural homogeneity across the Solomon Islands as a whole (section 2). The bulk of the paper (section 3) is then devoted to discussing in detail the extent to which various linguistic elements in the four Papuan languages do or do not conform to the Oceanic languages around them (section 4). Section 5 provides discussion and conclusions.

\section{CULTURAL HOMOGENEITY ACROSS THE SOLOMON ISLANDS}

2.1 SOCIAL CONTACT WITHIN THE SOLOMON ISLANDS. It is important to make clear at the outset that the Solomon Islands is not a completely uniform cultural area. This was also the case 100 years ago: as Rivers points out, "these islands [i.e., the Solomon Islands] are far from having a uniform culture" (Rivers 1909:167). However, there are strong commonalities across the region - and, of course, further flung into Bougainville and Vanuatu and beyond. Here we are interested only in the Solomons. Statements concerning the Solomons may also be true further afield - it is not my intention to exclude this. 
Like every indigenous group in the Solomon Islands, Vella Lavellans, Rendovans, Savo Islanders, and Russell Islanders live in small villages in houses made of bush materials. They are subsistence farmers reliant on gardening and, for coastal groups, fishing and shellfish collecting. Material culture has been changing in the last 100 or so years, but the changes are of a pattern as well. Thus, thatched roofs are being replaced with corrugated iron roofs, dugout canoes are being supplemented by fiberglass boats with engines, water tanks and taps are appearing in villages, and rice and tinned tuna are supplementing indigenous food supplies. There is plenty of evidence for sustained social contacts over large distances among the Solomon Islands. Hviding (1996:171) documents some of these:

The frequent raids in the mid-to-late nineteenth century, accelerated by the supply of European steel axes and firearms (McKinnon 1975), were part of complex regional systems of warfare, trade, and politics that involved the people of the New Georgia Group in networks ranging far beyond the archipelago to other parts of the Solomon Islands and entailing extensive, continuous spatial mobility. The people of the Roviana and Marovo Lagoons and of Simbo, Vella Lavella, Rendova, and other islands of the group went raiding and trading within the group, and also farther afield, across the ocean to Isabel, Choiseul, the Russell Islands, Savo, Guadalcanal, and more remote destinations (Findlay 1877:773).

Almost every aspect of material culture of the Solomons, of the sort described by Somerville (1897), is held in common across the whole region, even though there is some degree of regional specialization: for example, the Ghanongga people are known to be stone carvers while the Marovo people are wood carvers (Beth Evans, pers. comm.). ${ }^{2}$ Information on more specific items of material culture also suggests pan-Solomonic commonalities: for example, using spiders' web for fishing is done throughout the Solomons, and indeed as far away as Vanuatu. Zemp (1981) talks of different types of panpipes in various places over the Solomon Islands: methods of construction and tuning differ, but there are many points of identity, both within the Solomon Islands and also as far away as Papua New Guinea and Vanuatu.

Walter and Sheppard (2000) demonstrate cultural continuity from the archaeological past up until now. They mention shrines, wharves, canoe houses, house platforms, activity areas (that is, manufacturing areas), fortifications, and exchange valuables. This is documented for the Roviana culture area, but much of the information holds for the rest of the Solomon Islands.

Indeed, the flow of cultural items between the islands is ongoing today. When I was last in the Russell Islands, in 2003, a craze had swept in from Malaita of hitting PVC pipes of varying lengths with the sole of a thong to make music. The material elements are new, but the cultural borrowing follows ancient patterns.

Of great interest in this respect is the clan system, broadly shared across the whole Solomons. Fox talks of "exogamous clans with matrilineal descent ... and each clan has a totem, which is generally a bird (Fox 1919:101). Clan names are shared across some language borders: Fox says "the interesting point is that here we have clans quite new to San Cristoval" (Fox 1919:153). The Russells, too, have a new tribe (clan) - the process

2. This shared material culture is true of Papuan and Melanesian populations, but less so for Polynesian populations, which are not discussed here. 
of adoption of new clans and tribes seems to be widespread, and due to movement patterns like those described by Bathgate (1985).

For the Russells, Black (1963) mentions Lakwil and Kakau as two clans (tribes) found in Loun (east Russells) originating in Guadalcanal. Note that Hogbin also has these clan names, rendered by him as Lakwili and Kakau (among others), belonging to the northwest corner of Guadalcanal (Hogbin 1938:399). Indeed, Savosavo has Lakuili and Kakau among others (Claudia Wegener, pers. comm.).

2.2 TYPES OF SOCIAL CONTACT. There were two main kinds of relationships between islands in the Solomon Islands: headhunting relationships and marriage/trading relationships. Headhunting was directed from the west and to Guadalcanal, while trading was located from Guadalcanal toward Isabel and on to the Russells (Bathgate 1985).

Trading routes may be complex: for the Russells, Black (1963:6) notes the following relationships:

Before the war, people from Savo I. came to Karamalun with baskets which were exchanged for mats (kimita) and "umbrella" mats (folo) which are made by the women of Karamalun. Today these mats are bought by the people of Laona who take them to Visale on Guadalcanal and from there they move on to Savo. The baskets which come back in return are also purchased on a cash basis. ... In former times there were trade partners in the Russells and Savo but very few now have such "friends."

Critical to this discussion is that there is evidence tying Papuan-speaking groups to groups from the Austronesian-speaking islands, and no evidence of cultural separation in terms of material or nonmaterial culture. That this is noteworthy is shown by the existence of Polynesian groups in the Solomons: they have several aspects of material culture not shared by the rest of the Solomons, like outrigger canoes, houses built on the ground, and a unique cuisine. So it is not the case that mere residence in the Solomons necessarily endows a specific tool-kit and skill-set. Of course, the Polynesians are recent immigrants to the main Solomons group; were they to spend 3,000 years more in the Solomons, probably their culture would merge with that of the Oceanic and Papuan speakers. But in any case, the fact remains that the Papuan speakers have been interacting enough with the Oceanic speakers to have merged culturally, and the question then is: to what extent have the languages merged too? The rest of this paper addresses the linguistic question directly.

3. LEXICAL BORROWING. Thomason and Kaufman (1988) have shown that just about any linguistic feature can be transferred from one language to another (see also Curnow 2001). In the normal case of languages in contact, case studies show that the intensity of contact generally determines the amount and type of borrowing (Thomason 2001:70). The prediction is that, in general, lexemes are borrowed far more readily and frequently than structural features, and that, outside special conditions, there will be no borrowing of grammatical properties without prior lexical borrowing (Moravcsik 1978). Further, Tadmor, Haspelmath, and Taylor (2010:243) show that, in general, "nouns are borrowed much more often than verbs and adjectives, and that content words are borrowed much more often than function words." These formulations are 
useful for exploring the question of borrowing between Oceanic and Papuan languages in the Solomon Islands.

The discussion will begin with an account of lexical borrowing in each Papuan language, followed by an account of various grammatical features of Oceanic languages, to determine their presence or absence in the Papuan languages. The analysis will aim to enable an account of the exact type and amount of borrowing within each Papuan language.

In general there has been rather little lexical borrowing between the Papuan and Oceanic languages of the Solomon Islands. Tryon and Hackman (1983), for a roughly 200word extended Swadesh list, give the figures shown in table 1.

It is important to recognize that borrowing can go both ways: from Oceanic into Papuan languages, and vice versa. The approach taken here is that, if a shared lexical form is evidenced in a Papuan language and more than one Oceanic language, as long as the Oceanic witnesses appear in more than one major island group, or within a single island group but in many of the languages, the form is taken to be a loan from Oceanic into Papuan. If the form is only seen in one Oceanic language, or in a couple of contiguous Oceanic languages within an island group, then that form is taken as a possible loan from Papuan into Oceanic languages. Alternatively, any form that appears to reflect a Proto-Oceanic (POC) reconstruction is taken to be original to the Oceanic daughter languages, and its appearance in a Papuan language will be taken to have been through borrowing. Cases of both types will be identified and discussed below. However, unless otherwise mentioned, the loan has gone from Oceanic into Papuan.

In the discussion to follow, all Oceanic data are from Tryon and Hackman (1983), unless otherwise specified. In addition, Proto-Oceanic forms are given where known.

3.1 LEXICAL BORROWING INVOLVING BILUA. In Bilua, most borrowed words between any Oceanic language in Tryon and Hackman's list are nouns: many are body-part terms, for instance:

$$
\begin{array}{cll} 
& \text { BILUA OCEANIC } \\
\text { 'belly' } & \text { siapa } & \begin{array}{l}
\text { iapa-na (Lungga, New Georgia); tia-na (widespread in } \\
\text { New Georgia) }
\end{array} \\
\text { 'breast' } & \text { susu } & \text { widespread (POC *susu, Blust 1993) } \\
\text { 'ear', talina } & \text { widespread (POC *talina, Blust 1993) } \\
\text { 'egg' } & \text { toruru } & \begin{array}{l}
\text { toruru-na (Ghanongga), toruru (Lungga and Simbo), } \\
\text { (POC *[qa]toluR, Blust 1993) }
\end{array}
\end{array}
$$

Also, some numerals are shared, as with siakava 'nine' in Bilua compared to sia in many New Georgia languages (POC *siwa, Blust 1993). All the languages of the region have decimal number systems.

Nonbasic words that have been borrowed in Bilua include nouns like logge 'flyingfox', which has cognates in Choiseul and New Georgia languages. Other animals and

\section{TABLE 1. HIGHEST FIGURES OF BORROWING FOR EACH PAPUAN LANGUAGE WITH ANY OCEANIC LANGUAGE}

$$
\begin{array}{cccc}
\text { BILUA } & \text { TOUO } & \text { SAVOSAVO } & \text { LAVUKALEVE } \\
16 \% \text { (Ghanongga) } & 12 \% \text { (Roviana, Kusage) } & 20 \% \text { (Nginia) } & 10 \% \text { (Paripao) }
\end{array}
$$


birds include tono/tons 'hornbill' with cognates in Choiseul and New Georgia. There are many other borrowed animal names, as well as plant names such as varu 'Hibiscus tiliaceus', which is widespread throughout Choiseul and New Georgia and indeed further afield in the Solomon Islands, from POC *paRu (Ross, Pawley, and Osmond 2008:138). Many words relating to material culture are borrowed: for example, $k u^{m} \mathrm{bau}$ 'club', which is also found in Choiseul and New Georgia; $p a^{n} d e$ 'house', also found in Choiseul; sopere/ sopere 'spear', also in New Georgia; raka 'oven', also in Choiseul; and many more.

Verbs are borrowed to a very minor degree: the word given for 'cut (wood)' is cognate with the word for a club in other languages: $k o^{m} b u e / k o^{m} b u t o$. The word for 'kill', vouvato/vouvaiva, is possibly cognate with vuivale and similar forms in Choiseul; while pekao/pekava 'dance' is cognate with peka, which is widespread over New Georgia (the final $o$ in Bilua is a nominalizer; see Obata 2003:40). Similarly, kerao, kerao 'sing' is most likely cognate with kera in New Georgia, and zakei 'go up' may be cognate with saye/sayele in various languages of New Georgia, from POC * sake 'go upward, go southeast' (Ross, Pawley, and Osmond 2003:263).

Function words are a different story. Pronouns do not seem to be shared with any other language. Interrogatives and particles such as 'yes', 'no', 'here', 'there', 'because', 'left', 'right', and other conjunctions and function words are not shared. Neither are color terms or evaluative terms such as 'good', 'bad', or 'big', 'small', and other common modifiers. Two possible borrowed modifiers are vairu 'new', which is vər, vuru, varu'ga, varo'ga, voeru"ga in Choiseul languages and valgura and similar in some New Georgia languages; and mota 'thick', which appears in some New Georgia languages as mota and moata.

Note that the borrowing appears to go both ways; although the majority of words shared between Bilua and Oceanic languages appear to have come into Bilua from the Oceanic languages, this is not uniformly the case. Most of the words cited above appear both in Choiseul languages and in New Georgia languages. However, there are a few words that appear in only one or two New Georgia languages that are possible candidates for Papuan-Oceanic borrowing rather than the reverse. Such candidates include the following:

$\begin{array}{lll} & \text { BILUA } & \text { OCEANIC } \\ \text { 'sago palm' } & \text { pina } & \text { pina (Ghanongga and Lungga, Western Solomons) } \\ \text { 'cutnut' } & \text { rupe } & \text { rupe (Ghanongga and Lungga, Western Solomons) } \\ \text { 'sea' } & \text { ivere } & \text { ivere, ivere (Ghanongga, Lungga, and Simbo, } \\ & & \text { Western Solomons) }\end{array}$

3.2 LEXICAL BORROWING INVOLVING TOUO. Touo shows much less evidence of lexical interaction with its neighbors than does Bilua. Loans are only found among nouns; verbs and function words, as well as other word classes, are not represented among loans. Words that are borrowed include numerals, body parts, plants, animals, artifacts, and geographical entities. The following gives a flavor of the loans: ${ }^{3}$

TOUO OCEANIC

$\begin{array}{lll}\text { 'three' } & \text { hie } & \text { hike (some New Georgia languages) } \\ \text { 'thousand' } & \text { âro tina } & \text { keke tina, meka tina (some New Georgia languages) } \\ \text { 'breast' } & \text { susu } & \text { susu (etc., widespread, POC *susu, Blust 1993) }\end{array}$

3. Here and elsewhere the abbreviation "etc." should be read "and similar forms." 


\begin{tabular}{|c|c|c|}
\hline îsh' & iyana & $\begin{array}{l}\text { iyana, iya (etc., New Georgia, Guadalcanal, POC } \\
\text { *ikan, Blust 1993) }\end{array}$ \\
\hline 'pig' & mbo & $\begin{array}{l}\text { mboyoro, }{ }^{m} \text { boko (etc., Choiseul, New Georgia, POC } \\
\text { *boRok, Ross, Pawley, and Osmond forthcoming) }\end{array}$ \\
\hline 'clul & $\mathrm{ka}^{\mathrm{m}} \mathrm{ba}$ & $\begin{array}{l}\text { kumbau (etc., Bilua, Ghanongga-New Georgia, } \\
\text { Isabel) }\end{array}$ \\
\hline 'paddle' & voze & $\begin{array}{l}\text { vose, voze (etc., New Georgia, Guadalcanal, POC } \\
\text { *pose, Ross, Pawley, and Osmond 1998:199) }\end{array}$ \\
\hline & & mbae (New Georgia) \\
\hline & sayc & $\begin{array}{l}\text { sayaru (etc., New Georgia, POC *sakaRu, Ross, } \\
\text { Pawley, and Osmond 2003:104) }\end{array}$ \\
\hline
\end{tabular}

Interestingly, there are a few words that appear in Touo and local neighbors, but not elsewhere in Oceanic languages more widely. These are candidates for Papuan-Oceanic loans. Some examples follow:

(4)

\begin{tabular}{|c|c|c|}
\hline & TOUO & OCEANIC \\
\hline & $\hat{i}^{n} \mathrm{do}$ & $\mathrm{i}^{\mathrm{n}} \mathrm{d}$ (Ughele, New Georgia) \\
\hline 'headland' & miho & miho (Simbo) \\
\hline & $\mathrm{hi}^{\mathrm{i}} \mathrm{go}$ & he"ga (Kolombangara, Western Province) \\
\hline
\end{tabular}

3.3 LEXICAL BORROWING INVOLVING SAVOSAVO. Savosavo has more shared vocabulary with Oceanic languages than any of the other Papuan languages. Loans cover all domains. Many body parts are borrowed, including the following:

\begin{tabular}{lll} 
& \multicolumn{2}{l}{ SAVOSAVO OCEANIC } \\
'beard' & yolanola & yola-na (west Guadalcanal) \\
'blood' & yambu & yambu-na (etc., widespread) \\
'breast' & susu & susu (widespread, POC *susu, Blust 1993) \\
'feather' & sivuya & ivu-na (Guadalcanal) \\
'guts' & mboli & mbori-na, 'mori-na (Ghanongga and Lungga)
\end{tabular}

Numerals apart from mola 'million' do not appear to be borrowed. Some nonbasic vocabulary is borrowed; for example:

(6)

\begin{tabular}{|c|c|c|}
\hline & SAVOSAVO & OCEANIC \\
\hline rat' & kuzi & $\begin{array}{l}\text { kuhi (Gela, central Solomons, etc., POC *kasupe, } \\
\text { Blust 1993) }\end{array}$ \\
\hline & $\begin{array}{l}\text { mba }{ }^{\mathrm{m}} \mathrm{ba} \\
\text { yuliyuli }\end{array}$ & $\begin{array}{l}{ }^{\mathrm{m}} \mathrm{ba}^{\mathrm{m}} \mathrm{ba} \text { (some Guadalcanal languages) } \\
\text { yuyuri (etc., some Guadalcanal languages) }\end{array}$ \\
\hline
\end{tabular}

There are many more such examples. Some verbs are borrowed; for example, olo 'swim' is matched by olo/sh and similar forms in many Guadalcanal languages, and lelakeva 'walk' (actually analyzable as lela 'stroll' + keva 'do all about', Claudia Wegener, pers. comm.) is matched by lela in a couple of Guadalcanal languages. There are one or two examples of borrowed function words in the data: ${ }^{m}$ buriza 'after' is also found in Guadalcanal languages as muri-na, from POC *muri- 'back part, rear, be behind' (Ross, Pawley, and Osmond 2003:311-12). Note that in POC this word is a noun. Color

4. Note also Bilua vozi. 
terms are also shared: 'mbraya 'black', sisi 'red', and sere 'white' all have cognate forms in Guadalcanal languages.

The vast majority of the loans have gone from Oceanic languages into Savosavo, but there are also many examples where borrowing in the opposite direction could have occurred. An example of this is the word for 'love', which only appears in Savosavo (as ${ }^{n}$ dolo) and Gela ( ${ }^{n} \mathrm{~d} b$ b). In other cases, a word appears only in a small number of closely situated Guadalcanal languages, in which case the word could conceivably have been borrowed from Savosavo into all these at an earlier stage of their development, before they split off into different languages, or the word could have spread through the small group from Savosavo into all of them.

3.4 LEXICAL BORROWING INVOLVING LAVUKALEVE. In Lavukaleve, there has been considerably less lexical borrowing than in Bilua and Savosavo. From Tryon and Hackman (1983), Lavukaleve shares at most 10 percent with any Oceanic language. Both basic and nonbasic lexicon has been borrowed, and the semantics of the loan words suggests cultural and technological exchange between Lavukaleve speakers and their Oceanic neighbors, "particularly in the areas of seafaring, weapons and utensils used in daily life" (Terrill 2003b:382). Terrill (2003b) refers to loans into Lavukaleve in the domains of fish, bird, animal, and plant names; utensils, tools, and technological processes; and abstract cultural practices, like prayer, kin terms, and numbers. Some examples are given in table 2.

As with the other Papuan languages, most of the loans have been from Oceanic languages into Lavukaleve, but there are a couple of possible cases of loans going the other way: Terrill (2003b:383) cites fofo 'basin' < Proto-Southeast Solomonic (PSES) *popo

\section{TABLE 2. OCEANIC LOANS INTO LAVUKALEVE}

\begin{tabular}{|c|c|c|}
\hline 'million' & $\begin{array}{l}\text { LAVUKALEVE } \\
\text { mola }\end{array}$ & $\begin{array}{l}\text { OCEANIC } \\
\text { Lau (Malaita) mola 'ten thousand, used of things or of people' } \\
\text { (Ivens 1934) }\end{array}$ \\
\hline 'older brother' & kakal & $\begin{array}{l}\text { kaka (Tolo, Guadalcanal), 'father (vocative term)' (Smith } \\
\text { Crowley 1986), and also some Choiseul and Isabel languages }\end{array}$ \\
\hline 'family'* & kanege & POC *kainanga ‘descent group' (Hage 1998) \\
\hline 'tomorrow' & raine & $\begin{array}{l}\text { Cf. POC *raqani 'daytime, daylight' (Ross, Pawley, and } \\
\text { Osmond 2003:155-56,318-19), cf. Proto-New Georgia-Isabel } \\
\text { *rane 'day' (Ross 1988). Note the final } e \text { is a sporadic innova- } \\
\text { tion occurring only in New Georgia/Isabel languages, not } \\
\text { reflected elsewhere in Oceanic. }\end{array}$ \\
\hline 'blood' & ravu & ya $a^{m} b u-n a$ (Guadalcanal) \\
\hline $\begin{array}{l}\text { 'breast; nipple; } \\
\text { breastmilk' }\end{array}$ & susu & susu (widespread), РOC *susu (Blust 1993) \\
\hline 'man' & tam & $\begin{array}{l}\text { *tam }{ }^{\mathrm{w}} \text { ata 'man, husband' (Ross, Pawley, and Osmond 1998). } \\
\text { This could also be chance resemblance. }\end{array}$ \\
\hline 'sea' & tasi & $\begin{array}{l}\text { tahi 'salt' (Cheke Holo, White } 1988 \text { POC *tasik 'sea water, } \\
\text { salt water' (Ross, Pawley, and Osmond 2003) }\end{array}$ \\
\hline 'limb' & tau & $\begin{array}{l}\text { POC *tau 'body, person' (Ross, Pawley, and Osmond 1998). } \\
\text { This may also be chance resemblance, as the semantic connec- } \\
\text { tion is not strong. }\end{array}$ \\
\hline 'head' & vatu & $\begin{array}{l}\text { New Georgia languages mbatu-na 'head', Isabel languages } \\
\text { have } p^{h} a \text { ? } u \text {-na, POC * } \mathrm{p}^{\mathrm{w}} \text { atu(k) (Blust 1993). }\end{array}$ \\
\hline
\end{tabular}

\footnotetext{
* Specifically, parent and two or more children, if at least one of the group is male
} 
'wooden bowl's and koko 'drum' < PSES * yoyo 'slit-gong' as two examples of words that are present in local languages but not reconstructible to Proto-Oceanic.

There are also loans mutually shared by more than one Papuan language, for example:

$$
\begin{aligned}
\text { BILUA TOUO OCEANIC } \\
\text { 'cloth' titivi tivitivi Avasö (Choiseul) titivi, Lömbaumbi (Choiseul) } \\
\text { tetivi, from POC *tipi 'loincloth, man's garment' } \\
\text { (Ross, Pawley, and Osmond 1998:99) }
\end{aligned}
$$

In summary, general trends shared by all four Papuan languages are similar. Words for body parts, numbers, geographical terms, plants, and animals are frequently shared between Oceanic and Papuan languages. There are, however, few loans among verbs and function words, although these can on occasion be found. Most interesting are those few potential candidates for borrowing from Papuan into Oceanic languages.

4. STRUCTURAL BORROWING. Once it is known that the social situation exists that would be the necessary backdrop to linguistic borrowing, the next step is to present actual candidates. Given similarities of material and abstract culture between each Papuan language and its Oceanic neighbors, one can infer that each group has been in contact with at least one other group. None of the constructions to be described below can unequivocally be ascribed to borrowing. Rather, the aim of the next sections is to present various linguistic structures and assess the possibility that they appear in the respective languages through borrowing. The most that can be done is to make an inference that if particular linguistic features are shared between unrelated but neighboring languages, then the possibility exists that these shared features arise through borrowing on the part of one of the languages. In the sections to follow, various structural features that are candidates for having been borrowed will be discussed.

Note that table 3 in section 5 sets out the information in the following sections in tabular form.

4.1 PHONOLOGIES. Oceanic languages in this region typically have smallish phonemic inventories, with no complex articulations except prenasalized stops, and with stress being predictable. Bilua conforms exactly to this. Touo adds to this basic system the interesting distinction between breathy and normal voice in initial syllables, and a sixth vowel, $/ \mathrm{o} /$ There is only a marginal voicing distinction among stop consonants. Stress is predictable.

Lavukaleve's phonemic inventory is also interestingly different, with nonphonemic prenasalized stops and the so-called "Melanesian g" (a velar fricative or approximant), but in Lavukaleve there is a voiceless alveolar stop / $t$ /, a voiced bilabial stop / $/$ /, and only marginally the voiced alveolar $/ \mathrm{d} /$ and voiceless bilabial $/ \mathrm{p} /$. There is a phonemic voiced bilabial approximant. Further, stress is only largely, not completely, predictable. Also, it is possible that the $s$ phoneme is relatively recent in Lavukaleve, as it does not occur in any function words.

Savosavo has an extra palatal stop and nasal, and a voiced bilabial approximant, but otherwise conforms to the typical Oceanic phonology of the region. Stress is largely pre-

5. Interestingly, also popo in Savosavo (Claudia Wegener, pers. comm.). 
dictable, falling on the penultimate syllable, except for some cases of initial stress on some trisyllablic words (Wegener 2008:5).

Finally, like Oceanic languages (Lynch, Ross, and Crowley 2002), Bilua (Obata 2003:11), Touo (Terrill and Dunn, field notes) and Savosavo (Wegener 2008:5) have (C)V syllable structure, whereas Lavukaleve has a more complex (C)V(C) syllable structure (Terrill 2003a).

\subsection{PRONOUNS: TYPES OF PARADIGMS AND CATEGORIES.} Pronominal paradigms among the Oceanic languages of the region include free pronouns, possessor pronouns suffixed to bound nouns, and subject and object paradigms. Bilua largely conforms to this pattern, with proclitics marking subject, possessor, and person/ gender/number of NPs; clitics marking object; as well as pronominal enclitics marking person, gender, inclusion, and number of NPs (Obata 2003:48-49). Touo has free subject pronouns and object suffixes. It has an inclusive/exclusive distinction, three persons, and four numbers, adding a "known number" distinction to the typical singular/dual/plural system found elsewhere (Terrill and Dunn, field notes). Savosavo, too, has free pronouns, possessor pronouns (which are also free forms), and enclitic subject pronouns, as well as a set of emphatic pronouns (Wegener 2008:78ff). Lavukaleve is more different, with free pronouns, subject and object pronouns prefixed to the verb, and possessor pronouns suffixed to possessor nouns (Terrill 2003a).

Pronominal categories of Oceanic languages in the Solomon Islands are as follows: three persons, an inclusive/exclusive distinction, singular/dual/plural forms, and no gender (Lynch, Ross, and Crowley 2002:49). (Cheke Holo, spoken on Santa Isabel, is a rare exception to this in having a gender distinction.) The inclusive/exclusive distinction is very old and stable in the Austronesian family, which suggests the Papuan languages may have borrowed it. In Lavukaleve, there is evidence that the dual distinction in the personal pronouns may be of recent origin, as the dual pronouns are analyzable, being formed on the basis of the plural pronouns, but with the addition of a segment $l$, which is widespread in the language as a dual marker. There is, unfortunately, no similar evidence in other languages to point to the origin of the inclusive/exclusive distinction. With regard to gender marking, all four Papuan languages add to the Oceanic set with a gender distinction: four genders in Touo, three in Lavukaleve, and two in Bilua and Savosavo.

4.3 CONSTITUENT ORDER. Oceanic languages in the Solomons tend to have SVO or VSO constituent orders (Lynch, Ross, and Crowley 2002:49). Bilua is SVO and Touo, Savosavo, and Lavukaleve are SOV. Of interest in this respect is that while Bilua has SVO order, it also has postpositions, suggesting an earlier period of SOV order. This would bring it into line with Touo, Savosavo, and Lavukaleve, as well as many other Papuan languages. If this is the case, it is clear evidence of structural change as a response to Oceanic contact. This point will be returned to in the conclusions.

4.4 NP STRUCTURE AND ORDER OF ELEMENTS. Articles are rare outside Oceania, but they can be reconstructed for Proto-Oceanic. They have developed in interesting ways in the daughter languages, typically distinguishing number (singular and plural) and whether the noun is common or proper (Lynch, Ross, and Crowley 2002:38). In 
general, articles precede the head noun and modifiers follow the head noun in the Oceanic languages of the Solomon Islands. Roviana (New Georgia) provides an example of this: ${ }^{6}$

(8) ROVIANA
a. sa magu
DEF knife
'the knife'
b. qua vetu nomo-na
1 SG house big-3SG
'my big house'

(Corston-Oliver 2002:482)

(Corston-Oliver 2002:475)

In Roviana, categories associated with the articles are definite, indefinite, common, proper, number, enumeration, and focus, in various combinations (Corston-Oliver 2002:472-73).

In Bilua, articles (determiners) mark definiteness or indefiniteness. Articles precede the noun, as do modifiers. In the following example, $k o$ is the determiner and $m a$ a pronominal enclitic functioning as head of the modifier phrase (Obata 2003:78, 84):

(9) BILUA
a. $\mathrm{ko}=\mathrm{a} \quad \mathrm{kaka}=\mathrm{ka}=\mathrm{ma}$ meqora
3SG.F $=$ LIG older $=$ LIG $=3$ SG.F child
'the older daughter'
b. silo $=a=$ ma maba
small $=$ LIG $=3$ SG.F person
'a small woman'

(Obata 2003:85)

(Obata 2003:84)

In Touo, articles precede modifiers and nouns:

(10) TOUO
a. vo hwre
3SG.F.ART canoe(F)
'the canoe'
b. qe tebo bo
DEM big $\operatorname{pig}(M)$
'that big pig'

(Terrill/Dunn field notes)

(Terrill/Dunn field notes)

In Savosavo, too, all but two modifiers precede the head noun:
(11) SAVOSAVO
ighia ngai vaka $=$ gha
three big ship=PL
'three big ships'

(Wegener 2008:118)

Savosavo has a set of gender/number-marked determiners, which mark definiteness:

6. Glosses have been slightly modified for consistency. The following are the abbreviations not found in the Leipzig Glossing Rules: ABIL, abilitative; ATT, attributive; CERT, certainty; CONJ, conjunction; CW, clockwise; DS, different subject; EFOC, focus marker from heo paradigm; EMPH, emphasis; FIN, finite; INDEF, indefinite; LIG, ligature; N.1, first neuter noun class; NSUF, nominal suffix; O, object; PN, personal name; PNLOC, proper name location; PREP, preposition; PROPR, proprietive; PST, past; RCP, recent past; PRES, present tense; REAL, realis; REDUP, reduplication; RMP, remote past; SEQ, sequentive; SGP, singular possessor; SIT, situation change; thisR, within reach; thosen, nearby. Orthographies are those used in the works cited. 
(12) SAVOSAVO

Ko nyuba ko-va nini=e koi Poluku.

DET. SG.F child 3SG.F-GEN name-EMPH DET.SG.F PN

'The daughter's name (was) Poluku.'

(Wegener 2008:85)

In Lavukaleve, modifiers and articles follow the head noun:

(13) LAVUKALEVE

a. nga-uia tula

1SG.POSS-knife(F) small.SG.F

'my small knife'

(Terrill field notes)

b. fo'sal bakel ho'bea-m na

fish(M) big good-SG.M SG.M.ART

'the good big fish'

(Terrill field notes)

Bilua, Touo, and Savosavo, then, have determiners preceding nouns, like in Oceanic languages, while Lavukaleve is like Oceanic languages in having modifiers postposed to nouns.

4.5 POSSESSION. Oceanic languages make a distinction between two types of possession, called in the literature direct and indirect possession, referring to how the category is marked. The general semantic distinction corresponding to the two constructions is a distinction between alienable and inalienable nouns, although how exactly this plays out is different in each language (Lichtenberk 1985).

Longgu (Guadalcanal) will be used to exemplify the Oceanic situation. In Longgu there are two types of possession, direct and indirect (Hill 2002:546). Direct possession is generally used for inalienable possession, and indirect for alienable (there are fine semantic distinctions here, as described by Hill, that these two labels do not completely capture, but, in general, the labels are reasonably useful). Direct possession involves the possessed noun (child) followed by a possessor suffix (my) in (14a). In indirect possession, the head noun is followed by a postposed pronoun expressing person and number of the possessor (Hill 2002:546), as in (14b). In situations of generic possession, a third, associative, construction is used. The preposition $n i$, which elsewhere expresses purpose, separates the possessed item from the possessor, as in (14c).

(14) LONGGU

a. gale-gu

child-1SG

'my child'

(Hill 2002:553)

b. ivi gira $=$ gi

clothes $3 \mathrm{SG}=\mathrm{PL}$

'their clothes'

(Hill 2002:546)

c. rabo'o ni raurau

bowl PREP cabbage

'bowl of cabbage'

(Hill 2002:546)

Bilua, too, has direct and indirect possession. Under direct possession there is a possessor prefix on the possessed item, as in (15a). Indirect possession has the possessor NP 
marked with an enclitic 3rd person distal demonstrative, either vo (glossed 3SG.M, only for 3 rd person singular masculine referents) or $k o$ (glossed 3SG.F, for all other referents) (Obata 2003:101), as in (15b). The direct construction is used for inalienable possession. The indirect construction is used for other types of possession as well as other relational uses.

(15) BILUA
a. $\mathrm{O}=$ baerebaere poso 3SG.M=friend PL.M 'his friends'
b. $\mathrm{se}=\mathrm{ko} \quad$ zaloni 3PL=3SG.F ornament 'their ornaments'

(Obata 2003:99)

(Obata 2003:104)

Touo has general possession versus part-whole possession. In general possession, the possessor, which can be a noun or a pronoun, comes between the article and noun, that is, in the modifier slot.

(16) TOUO

$\begin{array}{lllll}\text { Zo yei yubuw (zo) yei } & \text { yigana } & \text { u-a. } \\ \text { 3SG.M.ART 1SG uncle 3SG.M.ART } & \text { 1SG } & \text { fish } & \text { take-REAL } \\ \text { 'My uncle took my fish.' } & & \text { (Terrill/Dunn field notes) }\end{array}$

Part-whole possession is expressed using juxtaposition, with the whole preceding the part:

(17) TOUO
va ha
house roof
'the roof of the house'

(Terrill/Dunn field notes)

In Savosavo, there is no formal distinction between different semantic types of possession. Possession is expressed either by a possessive pronoun, which can be preceded by a coreferential possessor NP (example 18a), by a possessive phrase (example 18b), or by a phrase involving the proprietive form lava (example 18c). For example:

(18) SAVOSAVO
a. possessive pronoun:
ko popo ko-va kuvikuvi
DET.SG.F bowl 3SG.F-GEN.M lid
'the bowl's lid
b. possessive phrase:
ai-va mau
1SG.GEN-GEN.M father
'my father'
c. proprietive lava:

(Wegener 2008:140)

(Wegener 2008:138)

Kuvikuvi lava $=$ e lo pa pera $=$ na.

lid PROPR.SG.M=EMPH DET.SG.M one basket=NOM

'The one basket has a lid.' (lit, 'Lid-having is the one basket.')

(Wegener 2008:99)

Unlike Oceanic languages and Bilua and Touo, but similar to Savosavo, Lavukaleve makes no distinctions between different types of possession, and has only one possessive 
construction, in which the possessor NP precedes the possessum, and the possessor is marked by a possessive prefix on the possessum:

(19) LAVUKALEVE

$$
\begin{array}{ll}
\text { ali na o-tail } \\
\text { man 3SG.M.ART } \\
\text { 'tha man'soss-house } \\
\text { the mouse' }
\end{array}
$$

(Terrill field notes)

Thus, of the four Papuan languages in the Solomons, only Bilua distinguishes alienable and inalienable possession. It is possible that Bilua's possessive marking system derives from that of some Oceanic language in its vicinity because, while structurally it uses prefixes (whereas the nearby Oceanic languages use suffixes to mark possession), functionally there are close parallels. That is, an original structure in Bilua has come to parallel the semantics of the Oceanic distinction.

4.6 SUBJECT CROSS-REFERENCE. Oceanic languages have the subject marker preceding the verb as standard, either as clitic, affix, or free form, and so do Touo, Bilua, Savosavo, and Lavukaleve, albeit in rather different ways. For example, in Kokota (Santa Isabel), there is a preverbal cluster of elements including markers of aspect and subject. The cross-referencing pronouns distinguish realis, irrealis, and neutral mood.

(20) кокотА

N-e-ke-ge toga.

REAL-3-PFV-PRS arrive

'He has just arrived.'

(Palmer 2002:509)

Similarly, in Bilua the subject cross-reference is a proclitic on the verb:

(21) BILUA

$\mathrm{O}=$ tatabarae $=\mathrm{k}=\mathrm{ala}$.

$3 \mathrm{SG} . \mathrm{M}=$ buy=3SG.F.O $=$ RCP

'He bought it.'

(Obata 2003:113)

In Touo, subject reference is marked not by affixation but only by a free pronoun or NP, with SOV constituent order:

(22) TOUO

Bere vo hwre nodo-v-a.

2DU.M 3SG.F.ART canoe(F) see-3SG.F.O-REAL

'They (two) saw the canoe.'

(Terrill/Dunn field notes)

Likewise, in Savosavo there is no subject cross-reference on the verb; rather, the subject can only be expressed as an NP before the verb:

(23) SAVOSAVo

$\mathrm{Ze}=$ na te ai lo gana=gha z-ovu-i.

3PL=NOM EMPH this DET.PL gun=PL 3PL.O-put-FIN

'They put up these guns.'

(Wegener 2008:164)

In Lavukaleve, there is either a prefix, as in (24a), or a suffix, as in (24b), marking subject on the verb: 
(24) LAVUKALEVE

a. Samataun oa vo-na vau e-lavea.
Samataun six 3PL.o-in go.seawards 1 1PL.EXCL-appear
'We arrived at Samataun at 6.'

'We arrived at Samataun at 6.'

(Terrill field notes)

b. Olang hola na fo'sal va ma-sev

because tree.sp(M) SG.M.ART fish(PL) PL.ART 3PL.POSS-tabu(M)

tuna-m fin.

be.really-3SG.M FOC

'Because hola is very tabu for fish.'

(Terrill field notes)

Person marking is extremely complex in Lavukaleve, and there are different systems depending on predicate type, focus construction type, and other factors. As far as the comparative situation is concerned, it is not obvious that one participant-marking system in Lavukaleve is older than the other.

Bilua seems to be the only Papuan language to systematically mark subjects with proclitics; in the other languages, there are either no proclitics/prefixes (Touo/ Savosavo) or they occur only under certain complex circumstances.

4.7 PREVERBAL TAM MARKERS. Preverbal TAM markers in Oceanic languages can be many and complex (Lynch, Ross, and Crowley 2002:45). For example, Kokota (Santa Isabel) has six preverbal slots for TAM categories. An auxiliary carries mood and subject agreement, and optional tense and aspect markers.

(25) КОКОТА

$$
\begin{aligned}
& \text { Ara ginai a-ke lao Buala. } \\
& 1 \text { FUT 1EXCL.SBJ-PFV go PNLOC } \\
& \text { 'I will go to Buala.' }
\end{aligned}
$$

(Palmer 2009:248)

Bilua also has six preverbal slots, for the pronominal clitic, aspect/mood markers, possessor-raising marker, object clitic, valency-increasing marker, and modifiers. The head is a verb, which may be accompanied by an object clitic if transitive, followed by a tense-mood marker (Obata 2003:111).

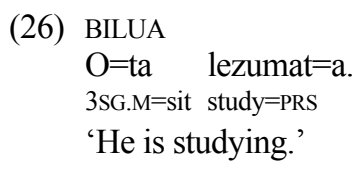

(Obata 2003:113)

Touo has preverbal and postverbal TAM marking. Tense, aspect, and negation both precede the verb and follow it. All independent verbs that are not in conditional or potential clauses are suffixed with one of two mood suffixes, realis or irrealis. Irrealis mood is used obligatorily with future tense, imperative mood, and negation. The realis marker occurs on all other verbs.

(27) TOUO

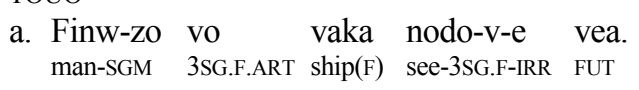
'The man will see the ship tomorrow.' (Terrill/Dunn field notes) 
b. Bere vo hwre nodo-v-a.

2DU.M 3SG.F canoe(F) see-3SG.F-REAL

'You two (m.) saw the canoe.' (Terrill/Dunn field notes)

The particle $b a$ (future, abilitative) precedes the verb while other future markers follow it:

(28) TOUO

Zavo yau nagw rue vaha bere ba reu vengw.

but NEG here CW side 2DU.M FUT/ABIL go FUT

'But you should not go to the clockwise side.' (Terrill/Dunn field notes)

Lavukaleve and Savosavo are strongly at variance here. There are no preverbal TAM slots in either of these languages. In Savosavo, TAM is marked by suffixes to the verb, in the outer layer of the two-layered verb structure:

(29) SAVosavo

a. ... pa sua $=$ na ba-zu

one giant=NOM come-PST.IPFV

'a giant came'

(Wegener 2008:331)

b. Teke-teke-a.

REDUP-hurry-IMP.SG

'Hurry.'

(Wegener 2008:341)

In Lavukaleve, tense and aspect are comparatively undifferentiated, and they are both marked by suffixes on the verb, or else by rather complex multipredicate constructions in which aspect is expressed by one of the predicates.

(30) LAVUKALEVE

Foe na a-kove-nu.

pig(M) SG.M.ART 3SG.M.O-look.for-PRS.SG

'He is looking for the pig.'

(Terrill 2003a:227)

Once again, there are certain parallels between Bilua's system of preverbal TAM markers (which could be a result of contact with surrounding Oceanic languages) and Touo's preverbal and postverbal marking, versus Lavukaleve's and Savosavo's TAM systems, which show no parallels.

4.8 OBJECT MARKING. In the Oceanic languages of the Solomon Islands, object reference is generally made by postverbal clitics or suffixes. In Kokota, "the object position consists of either an object indexed enclitic ... or an incorporated object" (Palmer 2002:510).

(31) КОКОТА

Ara n-a nomhi=ni ia mheke.

I REAL-1EXCL hear=3SG.O the.SG dog

'I heard the dog.'

(Palmer 2002:510; 2009:196)

In Bilua, this is an enclitic positioned between the verb stem and the tense marker:

(32) BILUA

... se ta ke ere $=\mathrm{v}=\mathrm{e}$ kala niabara

3PL TOP 3PL make=3SG.M.O=RMP INDEF.SG.M war.canoe

'... they made a war canoe'

(Obata 2003:79) 
Likewise, in Touo, objects are marked on transitive verbs by a suffix preceding the tense marker. (In the following example, the object is also marked by an agreeing free pronoun, with the subject unmarked.)

(33) TOUO

Zere yoro-n-a.

3DU.M call-3DU/TR-REAL

'(She) called the two boys.'

(Terrill/Dunn field notes)

In Savosavo, the object marker is in most cases a suffix on the verb; more rare are verbs that mark objects by prefixing, verbs that take both object prefixes and suffixes, and verbs that alter their stem to show object marking. An example of the most common situation, of object expressed by suffixation, is as follows:

(34) SAVOSAVO

Ke lo pa $=$ na pa savanga sua kola duku-li

CONJ DET.SG.M one=NOM one be.long ATT.SG.M stick cut-3SG.M.O

$\mathrm{ze}=$ lo bali-li.

CONJ=3SG.M.NOM sharpen-3SG.M.O

'So that one cuts a long stick and sharpens it.'

(Wegener 2008:336)

In Lavukaleve, the object is expressed either by a prefix on the verb marking person/ gender/number, as in (35a), or by a verbal suffix marking gender and number, as in (35b):

(35) LAVUKALEVE
a. Buku na a-o-fu.
conch(M) SG.M.ART 3SG.M.O-3SG.S-sing
'S/he blew the conch.'
b. Houl ma-kalaul a-le-re-v.
trees 3PL.POSS-roots 1SG.S-see-FUT-PL
'I will see tree roots.'

(Terrill field notes)

(Terrill field notes)

Whether prefix or suffix is used to cross-reference subject or object depends on argument structure and information structure types (Terrill 2003a, ch. 10).

Thus Bilua, Touo, and Savosavo (in most of its verbs) show similarity with Oceanic languages, while Lavukaleve, with its prefixes, does not.

4.9 INCORPORATED OBJECTS. Many Oceanic languages have incorporated objects. For instance, in Kokota, a nonspecific undergoer can be incorporated into the verb complex. Compare the following two examples, the first a normal undergoer object, cross-referenced on the verb, and the second incorporated, with no verbal cross-reference:

(36) КОКОТА
a. Ara n-a
korh-i=ri palu namhari are.
I REAL-1EXCL.SBJ pull-TR-3PL.O two fish thoseN
'I caught those two fish.'
I REAL-1EXCL.SBJ pull fish
'I caught fish.'
b. Ara n-a korho namhari.

(Palmer 2009:204)

(Palmer 2009:204) 
In Bilua, a similar situation arises in situations in which an NP is nonindividuated and nonreferential. Under these circumstances, an object is expressed not with the normal object enclitic but as a free-floating NP after the VP:

(37) BILUA

... ko ta ko=nabul $=$ a ko risu ... 3SG.F TOP 3SG.F=bake=PRS 3SG.F coconut.crab

'.. as for her, she coconut crab-baked ...'

(Obata 2003:152)

For comparison, below is a nonincorporated object: note the object agreement on the verb.

(38) BILUA

Koe loma quli ikio $\mathrm{ngo}=$ nabuli $=\mathrm{k}=\mathrm{a}$ ?

INTJ what thing FOC.NONF 2 SG=bake=3SG.F=PRES

'Oh, what are you baking?'

(Obata 2003:55)

Unfortunately, it is not known whether Touo has incorporation. In Savosavo, incorporated objects are not found (Claudia Wegener, pers. comm.). There is no parallel construction in Lavukaleve: arguments can never be incorporated. This is again an instance of Bilua patterning with Oceanic, and the other languages not.

4.10 LOCATIONAL EXPRESSIONS. Oceanic languages have prepositional phrases, as befits their VSO/SVO constituent order. For example, in Gela (central Solomons):

(39) GELA

E polo i muri-na na vale.

3SG.PST hide LOC behind-3SG ART house

'(S)he hid behind the house.'

(Crowley 2002:535)

Bilua is SVO but has postpositional phrases:

(40) BILUA

Vo ta $\mathrm{o}=$ beta $\quad$ papu $=\mathrm{a}$ toupa kale.

3SG.M TOP 3SG.M=CONT sit=PRES lake in

'He was sitting in a lake.'

(Obata 2003:182)

Touo, Savosavo, and Lavukaleve also have postpositional phrases:

(41) TOUO

$\mathrm{Na}$ fefa-na na oga wru tu-a.

3SG.N.1.ART paper-SG.N.1 3SG.N.1 floor on.top.of be-REAL

'The paper is on the floor.'

(Terrill/Dunn field notes)

(42) SAVOSAVO

Ekati=me dokta 1-omata bo ta-i.

CERT=2PL.NOM doctor 3SG.M-at go FUT-FIN

'You (pl.) will go to the doctor.'

(Wegener 2008:108)

(43) LAVUKALEVE

Janet kimita o-tat fufu-nu.

Janet mat(F) 3sG.F.O-on.top lie-PRES

'Janet is lying on a mat.'

(Terrill field notes)

All four Papuan languages differ from Oceanic languages in having postpositional phrases compared to the prepositional phrases of Oceanic languages. 
4.11 COMPLEX CLAUSES. Oceanic languages typically employ coordination as the main mechanism of clause linkage. In Bilua, the main strategy for clause linkage is coordination. In Touo, Savosavo, and Lavukaleve, clause chaining constructions exist as well as coordination. Some examples follow.

Kwaio (Malaita) has conjunctions joining coordinated clauses:

(44) KWAIO

A Dione ka feda-a éa ma ka aru-a i lalabata.

ART Dione 3SG fell-3SG cyathea CONJ 3SG put-3SG LOC clearing

'Dione felled a cyathea and put it in the clearing.' (Keesing 1985:195)

Bilua, too, has conjunctions joining coordinated clauses:

(45) BILUA

$\begin{array}{llll}\text { Vo ta o ol=a ju kale sukulu ju ni } & \text { ju } \\ \text { 3sG.M TOP 3SG.M go=PRES } & \text { water in stream water and } \\ \text { o=vaili=k=a } & \text { ko niuniu. } \\ \text { 3sG.M=look.for=3sGF.O.PRES } & \text { 3sG.F fish }\end{array}$

'As for him, he went to the big water, the stream (water), and he looked for fish.'

(Obata 2003:234)

Touo has clause chains consisting of medial verbs marked with a sequential marker, and final verbs carrying TAM and person marking:

(46) TOUO

Ede nae zere tiga na hugi-na o-e nae zere shoot.IRR SEQ 3DU.M finish 3SG.N.1 string(N.1)-SG.N.1 take-IRR SEQ 3DU.M

mw aovo-m-a.

3PL.M/F thread-3PL-REAL

'They speared them, then they took a string and threaded them on.'

(Terrill/Dunn field notes)

Savosavo has clause chains consisting of medial verbs marked with a same-subject marker, and final verbs carrying TAM and person marking. Same subjects across the medial clauses are marked with a special suffix, whereas different subjects are unmarked. In the following example, te is a neutral cosubordinator indicating sequence of events (Wegener 2008:286):

(47) SAVOSAVO

Sapi-ghi-a te=lo dai sou kiba zuvi-li-a

slice-3SG.F.O-SS CONJ=3SG.M.NOM good banana leaf cut.banana.leaves-3SG.M.O-SS

te $=$ lo ko polo savusavu-a-ghi k-ovu-a

CONJ=3SG.M.NOM DET.SG.F pig cover-EP-3SG.M.O 3SG.M.O-put-SS

te $=$ lo lo-va eghu bata-li-ghu=e.

CONJ=3SG.M.NOM 3SG.M-GEN.M fireplace line.up.stones-3SG.M.O.NMLZ=EMPH

' $(\mathrm{He})$ cut her into slices, and he collected a good banana leaf and he put it down (and) covered the pig and he built an oven.' (Wegener 2008:291)

Lavukaleve, too, has clause chains consisting of medial verbs marked with a sequential marker, and final verbs carrying TAM and person marking: 
(48) LAVUKALEVE

$\begin{array}{lllll}\text { Kino } & \text { ma-fong } & \text { na } & \text { a-ma-re } & \text { a-ma-re } \\ \text { cutnut.fruit(F) } & \text { 3PL.POSS-bunch(M) } & \text { SG.M.ART } & \text { 3sG.M.O-take-NF } & \text { 3sG.M.O-take-NF }\end{array}$

a-la-re a-na safu la o-foi.

3SG.M-open-NF 3SG.M.O-in parcel.of.nuts(F) SG.F.ART 3SG.F.O-hold

'Taking the bunch of cutnuts, taking them, cutting them open, she made a parcel of them.'

(Terrill field notes)

Bilua thus patterns with Oceanic languages in employing mainly coordinated clauses for clause combining, compared with the other three Papuan languages that have clause chaining constructions.

5. CONCLUSIONS. Table 3 summarizes the material covered so far on the phonology and grammar of the four Papuan languages of the Solomon Islands compared to general Oceanic patterns. The table is loosely based on the table found in Ross (2001a:141).

What is missing from the data is evidence of lexical calquing; this often precedes grammatical restructuring. However, the extensive dictionary evidence that would be needed to demonstrate lexical calquing is lacking. This is a promising area for future research.

\section{TABLE 3. MAJOR STRUCTURAL FEATURES MENTIONED IN EACH PAPUAN LANGUAGE}

\begin{tabular}{|c|c|c|c|c|}
\hline COMMON IN OCEANIC & BILUA & TOUO & LAVUKALEVE & SAVOSAVO \\
\hline \multicolumn{4}{|l|}{ Phonology } & largely \\
\hline phonemic prenasalized stops & no & yes & no & yes \\
\hline voicing distinction in stops & yes & marginal & marginal & yes \\
\hline "Melanesian $g "$ & no & yes & yes & yes \\
\hline (C) V syllable structure & yes & yes & no & yes \\
\hline \multicolumn{5}{|l|}{$\begin{array}{l}\text { Pronouns - types of paradigms } \\
\text { and categories }\end{array}$} \\
\hline INCL/EXCL & yes & yes & yes & yes \\
\hline SG/DU/PL & yes & and paucal & yes & yes \\
\hline no gender & $\begin{array}{l}\text { no (i.e., gen- } \\
\text { der present) }\end{array}$ & $\begin{array}{l}\text { no (i.e., gender } \\
\text { present) }\end{array}$ & $\begin{array}{l}\text { no (i.e., gen- } \\
\text { der present) }\end{array}$ & $\begin{array}{l}\text { no (i.e., gen- } \\
\text { der present) }\end{array}$ \\
\hline Constituent structure SVO/VSO & SVO & SOV & SOV & SOV \\
\hline \multicolumn{5}{|l|}{$\begin{array}{l}\text { NP structure and order of } \\
\text { elements }\end{array}$} \\
\hline articles & yes & yes & yes & yes \\
\hline noun-adjective & no & no & yes & no \\
\hline alienable/inalienable possession & yes & $\begin{array}{l}\text { yes (part-whole } \\
\text { vs. general) }\end{array}$ & no & no \\
\hline $\begin{array}{l}\text { Verb complex } \\
\text { prefix or enclitic subject } \\
\text { cross-reference }\end{array}$ & yes & no & yes & no \\
\hline preverbal TAM markers & yes & no & no & no \\
\hline enclitic or suffix object marking & yes & yes & yes/no & yes \\
\hline incorporated objects & yes & $?$ & no & no \\
\hline prepositional phrases & no & no & no & no \\
\hline $\begin{array}{l}\text { clause linkage devices, parataxis, } \\
\text { and conjunctions }\end{array}$ & yes & also chains & also chains & also chains \\
\hline
\end{tabular}


In 3.1, evidence was shown of a significant degree of lexical borrowing between Bilua and Oceanic languages, as well as between Savosavo and Oceanic languages, with Touo perhaps occupying an intermediate position and Lavukaleve showing the least effects of borrowing. In fact, Bilua, Touo, Savosavo, and Lavukaleve have responded quite differently to their Oceanic neighbors.

It is possible that any or all of Bilua's syllable structure, pronominal categories and paradigms, NP structure with preposed articles, possessive system, reduplication, subject and object marking, TAM marking, incorporated objects, subordination, and juxtaposition may potentially have an origin in Oceanic languages. Note that Bilua shows both structural similarities with Oceanic languages (for example, SVO order) as well as category similarities (for example, possessive classes, specific vs. nonspecific object distinction). There is a caveat, though. For most of these categories there is no strong evidence of structural borrowings: all that can be shown is that the social and geographical systems create the potential for borrowing to arise, and that the linguistic structures are suggestive.

What is most interesting and instructive is the difference in situation between Bilua on the one hand, and the other Papuan languages on the other. In Bilua, there is no direct evidence of borrowing from Oceanic, but there is evidence for massive structural realignment along the model of Oceanic languages. The evidence lies in the fact that Bilua has postpositions, but SVO word order, a historically unstable situation that strongly suggests linguistic borrowing or the beginnings of metatypy. By contrast, there are no serious candidates for structural borrowing into Lavukaleve from its Oceanic neighbors. Of the linguistic categories enumerated in this paper, it is only the pronominal categories that show any structural similarity with the Oceanic languages compared.

Touo and Savosavo seem to occupy an intermediate position in terms of structural borrowing. Candidates for borrowed structures from Oceanic languages into Savosavo include phonological and pronominal categories (though Savosavo expresses gender in its pronouns, unlike most Oceanic languages). Object marking, too, could be a candidate for a borrowed structure, but, if so, it is the only candidate. For Touo, candidates would be the structure of the verb phrase, some asspects of phonology, and possessive categories.

Evidence was presented at the beginning of this paper for the fact that social contacts have occurred throughout the Solomon Islands, and accordingly there are very many examples of shared material culture across the islands, with only minor differences. As far as material culture is concerned, there are no obvious differences between Bilua, Touo, Savosavo, and Lavukaleve. However, one cause of a different degree of linguistic borrowing might lie in their respective geography: Vella Lavella, the island where Bilua is spoken, is at the periphery of a hub of interaction between a number of islands, including Kolombangara, Ranongga, Gizo, and Simbo. Savo Island, by contrast, is a small outlying island off the coast of a major island, Guadalcanal, which has many languages of its own. There has, however, been close contact with Isabel (Bugotu speakers), Florida Islands (with some Gela speakers even living on Savo), and Guadalcanal (mostly Ghari and Lengo speakers, but also some on the Weathercoast), evidence being relational ties of Savo people to all these places, and also the shared clan names. The Russell Islands, by contrast, are far from any other islands and not part of a hub of interaction. While obvious similarities in material culture give testimony to a certain amount of social interaction, on 
the level of day-to-day interaction, there are many fewer opportunities for cultural and linguistic exchange in the Russell Islands. Touo is an interesting situation: it is similar to Savosavo in that it shares an island with an Oceanic language. This language is Ughele, which is closely related to Marovo and Roviana on New Georgia. There is evidence of long-term relationships between the two populations, in the form of some tribes (that is, clans) being held in common, indicating significant amounts of intermarriage. However, even though the two groups share an island, and intermarriage occurs, daily contact between them is limited. Even today, with logging roads and canoes with outboard motors, the journey to the north of the island is a long, rugged walk, or a long, rough sea journey. Day-to-day contact between these groups is not possible now, and was still less so presumably in the ethnographic past. This is reflected in the limited structural borrowing evidenced by Touo.

Thus, the different levels of linguistic interaction between Bilua and its neighbors versus Savosavo, Touo, and Lavukaleve and each of their neighbors could be largely a result of geographical circumstance. These four languages raise interesting questions about the differing roles of geography, social setting, and linguistic typology in contact-induced language change.

Finally, while the social situation was and is right for borrowing in all four languages, the linguistic situations do not strongly reflect this. Bilua presents some strong candidates for contact-induced language change, but Touo, Savosavo, and Lavukaleve do not. More work needs to be done to prove or disprove specific cases of structural borrowing, but from the preliminary work presented here it seems to be the case that a degree of structural borrowing has occurred from Oceanic languages into Bilua, but that in the case of Touo, Savosavo, and Lavukaleve, little to no structural borrowing seems to have occurred.

\section{REFERENCES}

Bathgate, Murray A. 1985. Movement processes from precontact to contemporary times: The Ndi-Nggai, west Guadalcanal, Solomon Islands. In Circulation in population movement: Some concepts from the Melanesian case, ed. by Murray Chapman and R. Mansell Prothero, 83-118. London: Routledge \& Kegan Paul.

Black, Robert H. 1963. The Russell Islanders of the British Solomon Islands Protectorate. Diploma of Anthropology thesis, University of Sydney.

Blust, Robert. 1993. Central and Central-Eastern Malayo-Polynesian. Oceanic Linguistics 32:241-93.

Corston-Oliver, Simon. 2002. Roviana. In The Oceanic languages, ed. by John Lynch, Malcolm Ross, and Terry Crowley, 467-97. Richmond, Surrey: Curzon Press.

Crowley, Terry. 2002. Gela. In The Oceanic languages, ed. by John Lynch, Malcolm Ross, and Terry Crowley, 525-37. Richmond, Surrey: Curzon Press.

Curnow, Timothy Jowan. 2001. What language features can be "borrowed." In Areal diffusion and genetic inheritance: Problems in comparative linguistics, ed. by Alexandra Y. Aikhenvald and R. M. W. Dixon, 412-36. Oxford: Oxford University Press.

Dunn, Michael. 2007. Vernacular literacy in the Touo language of the Solomon Islands. In Language planning and policy: Issues in language planning and literacy, ed. by A. J. Liddicoat, 209-20. Clevedon: Multilingual Matters. 
Dunn, Michael, and Angela Terrill. Forthcoming. Assessing the lexical evidence for a Central Solomons Papuan family using the Oswalt Monte Carlo Test. Diachronica.

Findlay, Alexander George. 1877. A directory for the navigation of the South Pacific Ocean: With descriptions of its coasts, islands, etc., from the straits of Magalhaens to Panama, and those of New Zealand and Australia, etc. Its winds, currents and passages. 4th ed. London: Published for Richard Holmes Laurie.

Fox, C. E. 1919. Social organization in San Cristoval, Solomon Islands. The Journal of the Royal Anthropological Institute of Great Britain and Ireland 49:94-179.

Hage, Per. 1998. Was Proto Oceanic society matrilineal? Journal of the Polynesian Society 107:365-79.

Hill, Deborah. 2002. Longgu. In The Oceanic languages, ed. by John Lynch, Malcolm Ross, and Terry Crowley, 538-61. Richmond, Surrey: Curzon Press.

Hogbin, H. Ian. 1938. Social organization of Guadalcanal and Florida, Solomon Islands. Oceania 8:398-402.

Hviding, Edvard. 1996. Guardians of Marovo Lagoon. Honolulu: University of Hawai'i Press.

Ivens, W. G. 1934. A vocabulary of the Lau language, Big Mala, Solomon Islands. New Plymouth, New Zealand: Thomas Avery and Sons Ltd.

Keesing, Roger M. 1985. Kwaio grammar. Canberra: Pacific Linguistics.

Lichtenberk, Frantisek. 1985. Possessive constructions in Oceanic languages and in Proto-Oceanic. In Austronesian Linguistics at the 15th Pacific Science Congress, ed. by Andrew Pawley and Lois Carrington, 93-140. Canberra: Pacific Linguistics.

Lynch, John, Malcolm Ross, and Terry Crowley. 2002. The Oceanic languages. Richmond, Surrey: Curzon Press.

McKinnon, John M. 1975. Tomahawks, turtles and traders: A reconstruction in the circular causation of warfare in the New Georgia group. Oceania 45(4):290-307.

Moravcsik, E. A. 1978. Language contact. In Method and theory, ed. by Joseph H. Greenberg, 93-122. Stanford: Stanford University Press.

Obata, Kazuko. 2003. A grammar of Bilua: A Papuan language of the Solomon Islands. Canberra: Pacific Linguistics.

Palmer, Bill. 2002. Kokota. In The Oceanic languages, ed. by John Lynch, Malcolm Ross, and Terry Crowley, 498-524. Richmond, Surrey: Curzon Press.

. 2009. Kokota grammar. Honolulu: University of Hawai'i Press.

Rivers, W. H. 1909. Totemism in Polynesia and Melanesia. The Journal of the Royal Anthropological Institute of Great Britain and Ireland, 39:156-80.

Ross, Malcolm. 1988. Proto Oceanic and the Austronesian languages of western Melanesia. Canberra: Pacific Linguistics.

- 2001a. Contact-induced change in Oceanic languages in north-west Melanesia. In Areal diffusion and genetic inheritance: Problems in comparative linguistics, ed. by Alexandra Y. Aikhenvald and R. M. W. Dixon, 134-66. Oxford: Oxford University Press.

. 2001b. Is there an East Papuan phylum? Evidence from pronouns. In The Boy from Bundaberg: Studies in Melanesian linguistics in honour of Tom Dutton, ed. by Andrew Pawley, Malcolm Ross, and Darrell Tryon, 301-21. Canberra: Pacific Linguistics.

Ross, Malcolm, Andrew Pawley, and Meredith Osmond, eds. 1998. The lexicon of Proto Oceanic: The culture and environment of ancestral Oceanic society, vol. 1, Material culture. Canberra: Pacific Linguistics.

. 2003. The lexicon of Proto Oceanic: The culture and environment of ancestral Oceanic society, vol. 2, The physical environment. Canberra: Pacific Linguistics.

. 2008. The lexicon of Proto Oceanic: The culture and environment of ancestral Oceanic society, vol. 3, Plants. Canberra: Pacific Linguistics.

. Forthcoming. The lexicon of Proto Oceanic: The culture and environment of ancestral Oceanic society, vol. 4, Animals. Canberra: Pacific Linguistics. 
Smith Crowley, Susan. 1986. Tolo Dictionary. Canberra: Pacific Linguistics.

Somerville, B. T. 1897. Ethnographical notes in New Georgia, Solomon Islands. The Journal of the Royal Anthropological Institute of Great Britain and Ireland 26:357-412.

Tadmor, Uri, Martin Haspelmath, and Bradley Taylor. 2010. Borrowability and the notion of basic vocabulary. Diachronica, 27(2):226-46.

Terrill, Angela. 2002. Why make books for people who don't read? A perspective on documentation of an endangered language from the Solomon Islands. International Journal of the Sociology of Language 2002(155-56): 205-19.

- 2003a. A grammar of Lavukaleve. Berlin: Mouton de Gruyter.

2003b. Linguistic stratigraphy in the central Solomon Islands: Lexical evidence of early Papuan/Austronesian interaction. Journal of the Polynesian Society 112(4):369-401.

Terrill, Angela, and Michael Dunn. 2003. Orthographic design in the Solomon Islands: The social, historical, and linguistic situation of Touo (Baniata). Written Languages and Literacy 6(2):177-92.

Thomason, Sarah G. 2001. Language contact: An introduction. Washington: Georgetown University Press.

Thomason, Sarah Grey, and Terence Kaufman. 1988. Language contact, creolization and genetic linguistics. Berkeley: University of California Press.

Thurston, William R. 1987. Processes of change in the languages of north-western New Britain. Canberra: Pacific Linguistics.

Tryon, D. T., and B. D. Hackman. 1983. Solomon Island languages: An internal classification. Canberra: Pacific Linguistics.

Walter, Richard, and Peter Sheppard. 2000. Nusa Roviana: The archaeology of a Melanesian chiefdom. Journal of Field Archaeology 27(3):295-318.

Wegener, Claudia. 2008. A grammar of Savosavo: A Papuan language of the Solomon Islands. Max Planck Institute Series in Psycholinguistics No. 51. PhD diss., Radboud Universiteit Nijmegen.

White, Geoffrey. 1988. Cheke Holo (Maringe/Hograno) dictionary. Canberra: Pacific Linguistics.

Zemp, Hugo. 1981. Melanesian solo polyphonic panpipe music. Ethnomusicology 25(3):383-418.

angela.terrill@mpi.nl 